\title{
SUSTAINABILITY AND EMPOWERMENT IN CONTEXT OF INCLUSION OF DISABLED PERSONS
}

\author{
Aldona Moceviciene \\ Lithuania \\ Gunars Strods \\ Rezeknes Augstskola, Latvia
}

\begin{abstract}
Creation without disassembling, using wisely, responsibleplaning and estimation longer-term consequences giving priority to the person, respecting his/her individuality, diversity - this is a new approach and sustainable society features. Quality of life include all aspects of the way we live our lives. They allow us to fulfil our needs and aspirations. On the basis of results of the research EU policy materials and Lithuania and Latvia ways of realization these laws in the regional policy, that all global methods and wellbeing development actions have a direct impact for people with intellectual disabilities and influent to expanding possibilities self-expression, activating self-action, stimulating self-conception. Creatiwity - the way and possibility in empowering these people socialization and self realizing. The researches in this field would answer to the questions: possible to optimize the quality of life for people with intellectual deseases in their abilities limited space.
\end{abstract}

Keywords: Sustainable development, Regional development, well-being, quality of life, empowerment, creatiwity, intellectually disabled, self-expression, self-action, limited abilities, inclusion.

\section{Introduction}

Sustainable development is one of most important the world development concepts. First time the Concept defined by the United Nations Commission on Environment and Development, headed by the then Minister for the Environment of Norway Gro Harlem Burndtland in the report „Our Common Future“ (1987). Will be correct if we say that sustainable development environmental, economical and social well-being for today and tomorrow for all human in the world.

When we think about the world as a system which connect space and time, then we also understand that quality of life is a system too and we can talk about holistic nature and holistic and humanistic philosophy of sustainable development.

It looks global concepts but realy they are closely connected to each of us, our environment. "The concept of sustainable development is rooted in this sort of systems thinking. It helps us understand ourselves and our world" - that is basic motives of IISD's (International Institute for Sustainable Development) staff, associates and board to innovate for a healthy and meaningful future for this planet and its inhabitants. 
Sustainable development combines three essential elements: economic, environmental and social development. In the United Nations documents, the following items are shown as interdependent and mutually reinforcing.

The European Council on June 2006 adopted the new EU Sustainable Development Strategy, which defines the responses to be adopted to tackle the principal sustainable development challenges: climate change and green energy; sustainable transport; sustainable consumption and production; threats to public health; social exclusion, demographics and migration; conservation and management of natural resources; the war on poverty in the world and the challenges in terms of sustainable development.

Whereas in this work developing problems of social integration, empowerment and inclusion, discussions about the conception of sustainable development will be in the social dimension area. As a part of this work relevant the guality will be investigate few aims of sustainable development: public health and social exclusion.

Values shows not words but works/actions. Observing and evaluating phenomena taking place around, we can find what is important and what is not for a modern man. Consumption growth marks the welfare rising. In the evolution of values occured changes causes difficulties to predict the consequences. Created by humans material of wealth must to serve man. Ideally if individual liberated from the difficult domestic survival problems may engage personal development, search the meaning of life and happiness. But in reality this does not happen.

Focus on man - respect, attempting to help and assist, decency and honesty in everyday life, business and policy should not be treated as signs of sentimentality. Ethics, morality, ability to share with others brings a long-term, stable and predictable positive change.

Long Western democracies experience shows that permanent, respectfull and trust-based relationship gives a birth a transparent and democratic policy, socially responsible business, according to the society and the needs of the individual and create considerably larger (gradually increasing) value, which in the long term perspective many times superiorthe instantaneous benefit.

\section{The Sustainable and Regional Development importance for disabled people well-being}

Regional policy - it is a public policy aimed at reducing social and economic disparities between regions. In the article we can distinguish the European Union (hereinafter - EU) and the Lithuanian national regional policy.

The main goals of European Union's regional (also called structural) policy are by series of measures (measured by GDP per capita) to reduce the level of nations, humans well-being and prosperity, to reduce the difference between the most and least developed regions of the EU. Lithuania by EU regional 
(otherwise know and notion as cohesion) policy terms is considered as a single region, which approachis to achieve the EU average economic development level. The main EU's instrument for the implementation of Regional policy Structural Funds. National regional policy, according to the Regional Development Act, is the state institutions and other entities targeted activities that have a differential impact on the state of regional social and economic development, in order to reduce regional socio-economic disparities and development differences within the regions, to promote stable and sustainable development throughout the country.

The formation and evolution of regional differences are determined by a variety of both internal and external factors. In a small country like Lithuania many external factors, that have a direct impact, can not be removed, possible only to mitigate the effects. That is why regional policy in Lithuania is compensatory nature, aimed in reducing the negative impact of external factors and focused on minimizing the differences between regions and within them. Regional policy in Lithuania undergoned several stages of formation, and at present the main objective of regional policy is the reduction economic and social disparities between regions.

In 2000 adopted the Regional Development Act (recasted in 2002) to develop and launch a regional development plans. The notion has been extended from the administrative to the social and economic development with the differentiated measures for a state social and economic policy. Appeared „target areas" conception which propose to see the region as a system that has certain structural parts: the center and periphery and the occupants, elements which have ties with the center and doing influence. At this moment in Lithuania is accented interaction between regional centers and socially less developed areas and regional centers strengthening their potential disclosure.

The situation is changed in the period 2007-2013, the European Union support planning period - began closer links between national and regional policy and the European Union cohesion policy. The aims and objectives of Regional policy were based on real financial instruments. At present, using the European Union support aims are not only declining differences between Lithuania and the European Union's economic, but declining the social and economic disparities between regions within a country too. Funding the programs led the reduction social and economic differences in the region's, and take real actions in the development of targeted areas (regional centers and problem areas) and to balanced more the distribution of EU support funding municipalities and regional councils initiated development projects.

In 2010 the European Commission adopted a document that defined the direction of the EU in the medium term - 2020: Strategy for Smart, Sustainable and Inclusive Growth, which identified the main priorities for the EU's enlargement in 10 years: intellectual growth, sustainable growth and inclusive growth, ensure social and territorial cohesion (Cohesion Policy 2014-2020) 
To implement this strategy, the European Commission and other EU institutions are planning to use a sufficiently wide range of instruments. At the moment the Regional Policy in Lithuania can be defined as a remedial activity, focused on minimizing the differences between regions and within them.

Given in mind Lithuania as state limited resources, regional policy is implementing in accordance of the two fundamental principles: Subsidiarity and Concentration.

Lithuania Regional policy long-term goal - to ensure a high quality of life for all residents of the country's territory. Lithuanian regional policy priority axis - equivalent Lithuania territorial socio-economic development.

Reviewing the sociologists, economics and business professionals J.Weiss, R.T. Georges, L. Nesh, R.A. Bucholz, S.K. Beylly, A. Cava and V. Pruskus published works and publications, it is possible to generalize and draw conclusions that the social welfare of society is very closely related with the consumption increaseing and well-established values and attitudes. The mentioned abowe authors analyzing the functioning of the human values, interaction and choice by market conditions. The values of the concept highlights the economic and cultural values and their diversity and the peculiarities.

Authors discuss about the market impact to individual self-determination and the values and influence of development of civil society, analyzed the problems adapting market principles in the areas of human life and the environment. The authors examine the produced comodities as good in useful options of market conditions, as well as importance economic and cultural values interoperability, ensuring the relatively stable society development in the face of globalization.

\section{Empowerment and social well-being}

The scientific literature society well-being analyzing in a broad and narrow sense. The first concept of prosperity is closely related to an objective concept of the welfare, well-being which includes economic aspects (socio-economic status, personal financial stability), medical aspects (health or sickness absence), political aspects (human rights). Narrow concept of the well-being is closely in connection to social psychology and describes the person experienced feelings and emotions (e.g., happiness, anxiety), also good moods of life being and satisfaction of needs (e.g., autonomy, a sense of closeness to others), external conditions (e.g., the financial conditions of life, incomes) and personal resources (e.g., health, strength, optimism, self-esteem).Well-being of high living person (i.e., daily experiencing positive feelings, in good moods and satisfying his/her needs) can be described as prosperous. Well-being also can be described as a life quality. Well-being includes personal autonomy (i.e., a sense that the person can control his/her life) and purpose of life. Negative emotions also have an impact 
on personal well-being, because improves willingness to face the new challenges, broadens personal resources and increases capabilities. Thus, the human happiness is not spontaneous him/herself purpose, but also a way to expand the possibilities to grow up personal well-being. It is important to distinguish well-being from what is having an impact. Well-being is affected by external factors (income, housing, education, social relations) and internal factors (health, optimism, self-esteem)

In the world (at the same time in Europe, Lithuania and Latvia too) have been many important political, social, economic and cultural life changes. Reducing public insularity, increasing migration and in diffusion of new lifestyles and behavior patterns, caused a stir on the social phenomena of which long time has been silent. Various sociology, psychology or philosophy books, studies, articles, discussions on web portals analyze these days relevant issues: violence and addictions, suicide, moral and economic poverty, people with disabilities exclusion.

Is done on a number of assumptions that the human individual as a social and cultural entity is necessary to belong to the community.

The community task - to educate someone to give him/her the opportunity to improve continuously, bring together, activate without altering communities substance. At present this process is popular to call - empowerment.

Empowerment refers the acquisition of power, capability to become a part of unit to do something.

Empowermen became the object of education and social work to help people or communities with difficulties. At present, the concept of empowerment is used in different contexts and situations. According to Barker (2003) empowerment is a support process that helps individuals, families, groups or communities to pursue personal, interpersonal, socio-economic and/or political power enhancement and conditions improvement. Empowerment is quite versatile and ambitious term describing the support for person, seeking $\mathrm{him} / \mathrm{her}$ to feel as valuable and useful member of society, raising the bar for selfesteem. Empowerment is a process that allows changes: in personal environment, environment in whole or both at the same time. Empowerment occurs when the person feels and is competetive to manage his/her social environment. In the process of empowerment is very important to eliminate and/ or prevent the occurrence of interference what violate the social justice, equality, human and community dignity. The process makes all possibilities to develop a creative environment: both in terms of personality development processes, both between each individual's environment to reach human and/or community wellbeing. 


\section{Creativity and intellecually disabled in the community}

In order to understand the possibilities of society, it is necessary to look objectively and soberly at the current environment, cultural traditions, declared and actuall the values, economic potential. Cultural traditions are changing the slowest. Rapid developments in this area usually does a lot of harm to the public welfare, which to repair take decades. Cultural revolution nowadays undesirable. More beneficial is community evolution and gradual maturation way - changing or deepening values in real life.

Nowadays widely are spoken and studying in many countries in the world (and in Europe, as well in Lithuania and Latvia) about how important disabled person integration, what approaches of disability should be and what is socialy right in the process of integration of disabled people. In the United Nations Convention on the Rights of Persons with Disabilities (UNCRPD) guidelines are encouraged to ensure inclusive development and launch a new movement for the rights of people with disabilities around the world. Convention proposes to reinforce the inclusion of people with disabilities not as a separate issue but as the tool of country's government's strategy implementation.

More than 30 years about that promotes Mobility Internation USA organization (MIUSA) and actively working in implementing innovative programs and building bridges to create a new era where people with disabilities will take their rightful place in the world community.

J.Vanier (2006) conveying the experience living in „Arc” community with people with intellectual disabilities marks that in the society, which emphasizes the strength and value, disabled people very difficult to find their place, because they are losing the battle for power. But, in turn, the weak - with a distinctive understanding of friendship - can affect and change the strenghts, if they only want to hear the voice of the ,bottom”.

Examined lot of the most famous these days social and economic policy experts and specialists articles, research can be summed that very important that all Regional policy instruments and funding should achieve targeted groups in the regions. analysis of authors such as D. Florida (2015) and J. Jauhiainen (2007, 2008) publications and books we can find that very important for regional socio-economic, sustainable development and community well-being is human creativity development in all aspects. Community can understand as a group of people with different economic and social status in the established territory, with different level of education, health, belong different age groups and gender, skin color, belonging to different religions and have different hobbies, occupation, lifestyle. All members in the community are straight connected to Regional policy searching goals and targeted objectives. Also all people can seach life quality and well-being using ongoing activities.

Regional policy influencing to the quality of life of persons with disabilities. This is a significant group of our society whose creative potential 
has not been developed enough and not known the impact and benefits of public welfare improvement. And this is a wide field of research.

The main factors limiting the mobility of persons with disabilities in the society and the activity is not adapted public and working environment, thus reducing the education and training systems, other public services. The structure of services for people with disabilities still dominated institutional care and very little development of other services. The possibilities for integration of the disabled reduces public stereotypes about them one and the skepticism about their abilities. In 2005 entered into force the Law of Social Integration began the shape a new concept of disability, which emphasizes the opportunities and importance to work, create, participate in the public activities. Therefore, special attention is paid to the social, professional, creative rehabilitation. The main problems encountered in the development of this system is too poorly developed infrastructure of services, qualified professionals in various rehabilitation chain and lack of work methods to ensure a comprehensive, continuous and efficient rehabilitation, education, training deficiency.

One of possible ways of intellectually disabled people incorporation in the society - to develop their creativity and artistical abilities.

Art could be and should be as everyday consumer product, community commodity which is very efficient but still is used little as a tool of communication and mutual understanding. Art sociology deals culture and art „using" concept and proves that art should be served to each person, depending on his/her needs and acceptation opportunities. Unfortunately, there is a lack of skilled human resources and difficult to achieve physical and spiritual wellbeing of the disabled person.

These professionals like luxury goods, which are purchased after the economic and spiritual crisis, when we will have plenty of bread, and we are abe able to play ... However, as the Romans used saying „,bread and games”, it must be at the same time ... Here and now ...

Examining the European Commission's documents, developing policies, strategies, social and economic policy experts and specialists articles the current extreme attention is paid and highlights in empowerment and giving priority to the person, respecting his/her individuality, diversity - this is a new approach and sustainable society.

Reviewing scientific literature scientific articles, studies and publications referred above, possible to make a general conclusion - what aspects hinders and what aspects make influence in the process of disadvantaged people inclusion, what is presented on Figure 1.

The situation of person exclusion is influenced by factors mentioned in Figure 1: social and economic status, lack of education, life unfortunate situation and health condition. Developing social and individual potential possible to reduce the situation of marginalization and to find new models and opportunities for inclusion. 


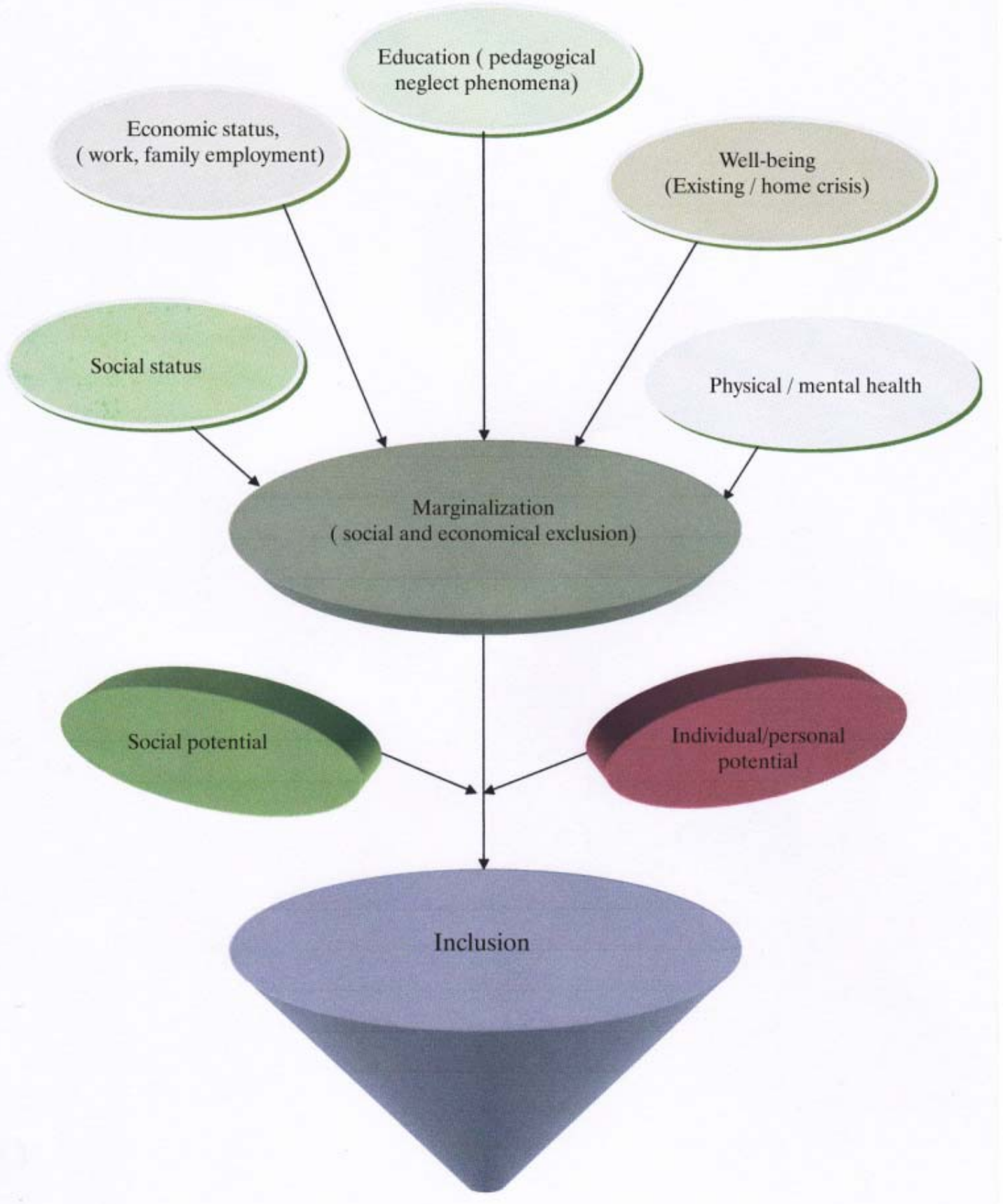

Figure 1. The aspects of inclussion process of socially disadvantaged persons

\section{Conclusion}

Inclusion as social phenomena, which long time has been silent, must be as one of priorities in developing comune wellbeing. Analyzing various sociology, psychology or philosophy books, studies, articles, discussions on web portals we need to talk about people with disabilities exclusion and the ways to empower them one and find ways for inclusion into society. They are part of our society and they must be included in devloping his/her personal quality of life, commune and society well-being, what directly influenced by the region's economic and social welfare increases, sustainable development policy. 
All people can search life quality and well-being using ongoing activities. Empowerment allows changes in personal environment and social environment around him/her. It is very important to eliminate and / or prevent the occurrence of interference what violate the social justice, equality, human and community dignity.

All global methods and wellbeing development actions have a direct impact for people with intellectual disabilities and influent to expanding possibilities self-expression, activating self-action, stimulating self-conception. Creatiwity - the way and possibility in empowering these people socialization and self - realizing.

Time to revise the integration of people with disabilities into society stereotypes, politics, apply flexibile innovations and alternative models and methods. Thus, the debate about the creativity need for personal self-esteem and self-awareness development and influence to public welfare growth, begins.

\section{References}

Barker, L. R.(2003). The Social Work Dictionary, 5-th Edition. NASW Press, ISBN-13: 9780871013552

Beržinskas G. (2002). Etika gyvenime ir versle. Vilniaus Universiteto leidykla Beylly S.K. (1998) Ethics in public service.Public Administration and Democracy: Essays in Honor of Paul Appleby. New York:Syracuse University Press, pp. 283-298.

Brundtland, G.H. (1987). Our Common Future: Report. Retrieved from: http://worldin balance.net/intagreements/1987-brundtland.phpiterature (Access: 2014-12-20)

Cohesion Policy 2014-2020 - Investing in Growth and Jobs / European Commission. (2011). Luxembourg: Publications Office of the EU, 20 p. International Institute for Sustainable Development, http://www.iisd.org/(Access: 2014-12-20)

European Commission's DG for Employment, Social Affairs \& Inclusion. Social investment $\mathrm{http}: / /$ ec.europa.eu/social/main.jsp?catId=1044\&langId=en (Access: 24-01-2015)

European cooperation in education and training ('ET 2020')

http://eur-lex.europa.eu/legalcontent/EN/ALL/;ELX_SESSIONID=P6LVJDYp4VZhjIRXP GpT2wLC8ND9gnDw20hC2d51QGTyFPgY9NhF!-845408605?uri=CELEX:52009X G0528(01) (Access: 20-12-24)

Europe 2020 - A Strategy for Smart, Sustainable and Inclusive Growth. Communication from the Commission [Electronic resource]. - Brussels, 3.3.2010. COM(2010) 2020 final. http://eurlex.europa.eu/LexUriServ/LexUriServ.do?uri=COM:2010:2020:FIN:EN:PDF (Access: 20-12-2014)

Florida, R. (2015). The Global Cities That Power the World Economy Now. http://www.citylab.com/work/2015/01/global-cities-power-the-world-economy/384732/ (Access: 27-01-2015)

Florida, R. (2015). Is Your Neighborhood Changing? It Might Be Youthification, Not Gentrificationhttp://www.citylab.com/housing/2015/02/is-your-neighborhoodchanging-it-might-be-youthification-not-gentrification/385193/(Access: 27-01-2015)

Gordon J. A.,Buchholz A. R. (1978). Corporate Social Responsibility and Stock Market Performance. Academy of Management Journal, September 1, vol. 21 no. 3 479-486 $10.2307 / 255728$

Grinius J. (1998). Žmogaus problema technikos amžiuje. Vilnius, Aidai

Helen Clark:. Speech at the Global Launch of the 2014 Human Development Report. http://www.undp.org/content/undp/en/home/presscenter/speeches/2014/07/24/helen- 


\section{SOCIETY. INTEGRATION. EDUCATION. Volume III}

clark-speech-at-the-global-launch-of-the-2014-human-development-report-sustaininghuman-progress-reducing-vulnerabilities-and-building-resilience-/ (Access: 02-02-2015) Human development Report $2014 \mathrm{http} / / \mathrm{www}$.undp.org/content/undp/en/home/librarypage/ hdr/2014-human-development-report/ (Access: 12-01-2015)

Jauhiainen, J. S.(2008) Regional and Innovation Policies in Finland - Towards Convergence and/or Mismatch? http://academic.research.microsoft.com/Publication/42496455/ regional-and-innovation-policies-in-finland-towards-convergence-and-or-mismatch (Access: 28-01-2015)

Jauhiainen, J. S.(2007)Men, money and mobile phones: Tracing the technology discourse in Finnish newspapers. http://academic.research.microsoft.com/Publication/41095522/ men-money-and-mobile-phones-tracing-the-technology-discourse-in-finnishnewspapers (Access: 28-01-2015)

Jerkins J. (1997). Šiu laiku dorovinès problemos. Vilnius, Alma Littera.

Lewis V.P. Ethical principles for decision makers: A longitudinal survey. Journal of Business Ethics, April 1989, Volume 8, Issue 4, pp 271-278

http://link.springer.com/article/10.1007\%2FBF00383341(2015-01-28)

Lietuvos Respublikos regioninés plètros istatymas

http://www3.Irs.lt/pls/inter3/dokpaieska.showdoc_1?p_id=482924\&p_tr2=2

http://ec.europa.eu/eurostat/statistics-explained/index.php/Main_Page/lt

Nutarimas dèl 2014-2020 metu nacionalinès pažangos programos patvirtinimo http://www3.1rs.1t/pls/inter3/dokpaieska.showdoc_1?p_id=439028\&p_query=\&p_tr2=2 (Access: 08-11-2014)

OECD (2014), How's Life in Your Region?: Measuring Regional and Local Well-being for Policy Making, OECD Publishing, Paris. http://dx.doi.org/10.1787/9789264217416-en (2015-01-12)

Pruskus V. Vertybès rinkoje: sqveika ir pasirinkimas (2005). Lietuvos edukologijos universiteto leidykla,ISBN 9955-20-002-2

Pruskus V. (2003). Verslo etika. Laiko iššūkiai ir atsako galimybès. Vilnius, ISBN 9986-43304

Rakauskienè O.G., Servetkienè V. (2011). Lietuvos gyventojų gyvenimo kokybė dvidešimt metu rinkos ekonomikoje. Monografija. Vilnius: Mykolo Riomerio universiteto leidybos centras

The Act Equal Opportunity. 1st fo January 2005. No IX - 1826. Vilnius

Van Der Gaag A., Dormandy K. (1993). Communication with Adults with Learning Disabilities. London, Whurr Publications.

Vanier, J.(2006) Kiekvienas žmogus-šventa istorija. Vilnius, Katalikų pasaulis

World Urbanization Prospects: The 2009 Revision. Highlights [Electronic resource] / United Nations, Department of Economic and Social Affairs, Population Division. (2010)

http://esa.un.org/unpd/wup/Documents/WUP2009_Highlights_Final.pdf. (Access05-01-2015)

Šinkūnienè J.R. (2005). Muzikinès komunikacijos ugdymo metodinès kryptys. Neigaliuju meninis ugdymas.Vilnius: Kronta.

Фатеев, В.С. (2012). Инновачионная, промьлиленная и региональная политики Европейского союза: опыт применения и новые перспективы их координации в 2014-2020 г2. Экономический рост Республики Беларусь: глобализация, инновационность, устойчивость: материаль $V$ Междунар. науч.-практ. конф. Минск: БГЭУ, (1) 217-218 p.

Фатеев, В.С. (2011). Мировые тенденции регионального и городского развития и их преломление в Беларуси http://ekonomika.by/downloads/Fateev_2011-1.pdf(Access: 27-01-2015) 